С. Ю. Назаренко, к.т.н., доцент, дои. каф. (ORCID 0000-0003-0891-0335)

Г. О. Чернобай, к.т.н., доиент (ORCID 0000-0001-8805-3710)

О. М. Колєнов, к.держ.упр., заст. нач. факультету (ORCID 0000-0002-3736-9165)

П. Ю. Бородич, к.т.н., доцент, доч. каф. (ORCID 0000-0001-9933-8498)

Б. I. Кривочей, к.т.н., доцент, дои. каф. (ORCID 0000-0002-2561-5568)

B. O. Timapeв, фахівець відділу (ORCID 0000-0002-3183-1689)

Наџіональний університет иүивільного захисту Украӥни, Харків, Украӥна

\title{
ВИЗНАЧЕННЯ В'ЯЗКОПРУЖНИХ ВЛАСТИВОСТЕЙ НАПІРНОГО ПОЖЕЖНОГО РУКАВА ДІАМЕТРОМ 150 ММ
}

Представлені експериментальні дослідження з визначення в'язкопружних характеристик напірного пожежного рукава типу «Т» із внутрішнім діаметром 150 мм в умовах статичного навантаження. В ході роботи проведено низку натурних експериментів на розтяг зі зразком в умовах статичних циклів навантаження-розвантаження. Випробування складались 37 циклів (режими) навантаження-розвантаження, які проводилися із двохвилинним інтервалом. 3 урахуванням експериментальних даних визначено жорсткість при розтяганні матеріалу рукава у поздовжньому (вздовж основи) напрямку. Встановлено, що чисельні результати механічних властивостей залежать від «історії» навантаження рукава, тобто на перших двох режимах навантаження приведена жорсткість збільшувалися і лише потім на наступних - стабілізувалися. Вказане, разом із суттєвим зменшенням залишкових деформацій, посилює пружні властивості матеріалу пожежного рукава. Результати проведених досліджень показали, що при перших двох циклах матеріал демонструє прояв короткочасної повзучості, яка стабілізується на 5-7 режимі. Для узагальнення експериментальних досліджень результати апроксимовані відповідними лініями трендів. Було визначено криві деформування зразків, що в умовах циклічного навантаження-розвантаження формували петлі гістерезису. При аналізу відповідних кривих було встановлено, що: по-перше, при перших двох трьох циклах навантаження-розвантаження зменшується площа петель гістерезису. По-друге, кут нахил петель гістерезису при кожному наступному циклі навантаження-розвантаження також зменшувався. Встановлено, що коефіцієнти дисипації матеріалу рукава при розтягу у поздовжньому напрямку при перших двох, трьох режимах випробувань збільшується. При наступних випробуваннях (цикл 4-7) коефіцієнти дисипації зменшуються а потім стабілізуються на рівні 0,42.

Ключові слова: напірний пожежний рукав, модуль пружності, жорсткість, гістерезис, дисипативні властивості

\section{1. Вступ}

Сучасний розвиток промисловості характеризується застосуванням та розширеним використанням композитних матеріалів, що складаються з еластомірної, зокрема гумової, матриці та різноманітного кордного посилення. Цей вид матеріалів активно застосовується у сучасній техніці, будівництві, автомобілебудуванні, апаратах і приладах. Зокрема, широке застосування знайшли спеціальні шланги та напірні рукава, які у якості гнучких трубопроводів здійснюють транспортування під високим тиском різних рідин, газів, пару, пульпи, абразивних сумішей та сипучих матеріалів.

Варто відмітити важливу роль різного типу гнучких трубопроводів, наприклад, напірних пожежних рукавів (НПР), які використовуються для гасіння пожеж. Вважається, що цей вид пожежно-технічного оснащення має найменшу надійність серед інших. Раптовий їх вихід з ладу може стати причиною зростання тривалості проведення оперативних робіт та розливу небезпечних хімічних речовин в місцях руйнування, що збільшить масштаб негативних екологічних наслід- 
ків. 3 метою недопущення цього проводиться технічне обслуговування НПР, яке також включає діагностування їх технічного стану але навіть ці заходи не запобігають їх раптовому виходу з ладу. Це пов’язано з наявністю прихованих дефектів в матеріалі з якого виготовлені ці гнучкі трубопроводи, що не завжди можливо виявити із застосуванням відомих методів діагностування.

Проблемою на сьогоднішній день $є$ те, що способи випробування НПР, що застосовуються в аварійно-рятувальних формувань, не дозволяють діагностувати технічний стан рукава на ранній стадії його пошкодження (до розриву). Тому актуальним $є$ розробка та удосконалення способів випробування, що дозволяють визначити наявність дефекту до настання граничного стану (розриву), при виявлені якого може призвести до збільшення часу ліквідації НС.

\section{2. Аналіз літературних даних та постановка проблеми}

Руйнування гнучких трубопроводів може відбуватися 3 різних причин. Одними з цих причин $є$ пошкодження в місцях кріплення гнучкого трубопроводу до втулки [1] або руйнування безпосередньо самого фітинга [2]. Перше згідно [1] відбувається через те, що втулка з'єднувальної арматури може мати необроблені гострі краї, які вже під час монтажу викликають пошкодження, а також $з$ причини втрати еластичності матеріалу з якого виготовлені гнучкі трубопроводи, що спричиняє появу нещільностей в місцях приєднання. Іншою причиною $\epsilon$ виробничі дефекти з'єднувальної арматури, які в період експлуатації зумовлюють іiі руйнування [2].

Згідно [3] процес оцінки граничної міцності гнучких трубопроводів $\epsilon$ складним, що пов’язано з їх багатошаровою структурою і використанням різних матеріалів. Відповідно зміна фізичних властивостей кожного матеріалу під дією різних зовнішніх впливів, наприклад при взаємодії з нафтопродуктами, може відбуватися по різному [4]. Одні матеріали взаємодіють активно і тому швидко відбувається зміна їх фізичних властивостей, а деякі проявляють незначну взаємодію, що пояснює складність процесу прогнозування їх поведінки.

Руйнуванню матеріалу 3 якого виготовлені гнучкі трубопроводи сприяє поява на його поверхні мікротріщин, які згідно [5] можуть 3'являтися в результаті виникнення напруження і циклічних деформацій. В дослідженнях [5] проводиться оцінка процесу втоми лише еластомерів, які входять до складу матеріалу з якого виготовлений гнучкий трубопровід. У той же час, як стан тканинного армуючого шару до розгляду не приймається.

3 метою прогнозування ймовірних деформацій гнучкого трубопроводу можуть бути застосовані методи гомогенізації та інтерполяції [6] але, при цьому, необхідно приймати деякі спрощення під час розгляду структури матеріалу та певні усереднені значення параметрів, що веде до погіршення достовірності отриманих результатів.

В роботі [7] запропоновано математичну модель, яка дозволяє оцінити граничне значення тиску в середині трубопроводу при якому може статися його руйнування. На жаль, вказана модель не враховує втому еластомерів, які входять до складу матеріалу з якого виготовлені гнучкі трубопроводи.

Згідно [8] значення розривного тиску гнучких трубопроводів залежить від розривного зусилля уткових ниток, радіусу рукава, діаметру ниток основи та утку, коефіцієнта вертикального зминання ниток основи та утку. Математична Civi1 Security. DOI: 10.52363/2524-0226-2021-33-12 
модель, яка запропонована в цій роботі, при врахуванні названих раніше чинників дозволяє оцінити розривний тиск НПР. Властивості еластомерів, які входять до складу матеріалу з якого виготовляють НПР ця математична модель не враховує.

В роботі [9] експериментальним шляхом були досліджені механічні властивості НПР типу «Т» із внутрішнім діаметром 66 мм в умовах статичного навантаження шляхом прикладення до нього певного стандартного зусилля, що дозволило встановити значення модуля пружності при розтягуванні матеріалу рукава у поздовжньому напрямку. Згідно [10] механічні властивості гнучких трубопроводів можуть також змінюватись під час закручування їх на певний кут. В цій роботі досліджувалися механічні властивості дослідних зразків НПР типу «Т» із внутрішнім діаметром 77 мм, які мали різні значення внутрішнього гідравлічного тиску при зміні кута закручування. Дослідні зразки, які були використані в дослідженнях [9, 10] перед проведенням експериментів не мали жодних пошкоджень.

Провести діагностування технічного стану гнучких трубопроводів можна 3 використанням методу промислової комп'ютерної томографії [11] але у випадку, коли трубопровід виконаний із композитного матеріалу певного складу цей метод може бути не застосованим, що обмежує його використання.

В роботі [12] було розглянуто питання щодо досліджень міцності та удосконалення будови силового каркасу (ткацького чохла) напірних пожежних рукавів. Встановлено, що при розрахунках міцності силового каркасу не враховується різність волокнистого складу матеріалу, щільність та діаметр ниток як по основі так і по утку. Це зумовило до більш детального вивчення цього питання. Так розглянуто питання щодо удосконалення конструкції армуючого каркасу рукава за рахунок зміни діаметру ниток, геометричної щільності тканини (основи та утка) від розривного тиску. Встановлено, що: по-перше, при збільшенні геометричної щільності армуючого каркасу як по основі так і по утку розривний тиск зменшується, визначено найбільш ефективну щільність матеріалу. По-друге, при збільшені діаметру ниток основи (утка), розривний тиск збільшується (зменшується). По-третє розривний тиск пожежного рукава прямо пропорційно розривному зусиллю уточних ниток і обернено пропорційно радіусу пожежного рукава при постійності всіх інших параметрів (щільність матеріалу, діаметр ниток). Ця робота направлена на удосконалення конструкції НПР. В свою чергу ці результати доводять, що при конструюванні НПР використовуються різні діаметри основної та уточної нитки. Наявність різного діаметру ниток призводить до ортотропії в'язкопружних властивостей матеріалу рукава. Для визначення констант ортотропії матеріалу рукава, застосовуються методи комп'ютерного моделювання або експериментальне випробування відповідних характеристик матеріалу. Тому постала необхідність у визначенні механічних властивостей матеріалу рукава у поперечному напрямку експериментальним випробуванням.

Таким чином, встановлено, що більшість 3 проаналізованих робіт пов'язані 3 дослідженнями зміни властивостей матеріалів 3 яких виготовлені гнучкі трубопроводи під дією на них різних впливів [1-10]. 3 метою діагностування технічного стану гнучких трубопроводів може бути застосований метод промислової комп'ютерної томографії [11] але складність структури матеріалу 3 якого вони виготовлені обмежує його застосування. Через складну будову 
гнучких трубопроводів в ряді робіт [4-8] досліджується зміна властивостей лише окремих шарів 3 яких складається матеріал 3 якого їх виготовлять. Комплексна оцінка зміни механічних властивостей матеріалу 3 якого виготовлені гнучкі трубопроводи при різних впливах на нього досліджуються в роботах $[9,10]$. В цих роботах не дослідженим залишається характер зміни механічних властивостей матеріалу з яких виготовлені гнучкі трубопроводи при наявності в них дефектів. Дослідивши ці властивості можна буде виконати порівняння їх iз механічними властивостями зразків, що не мають дефектів i, на основі цього, зробити висновок про їх технічний стан.

Тому постала необхідність у визначенні механічних властивостей НПР різного типу та діаметру рукава. Дослідивши ці властивості можна буде виконати порівняння їх із механічними властивостями зразків, що мають дефекти i, на основі цього, зробити висновок про їх технічний стан.

\section{3. Мета та завдання дослідження}

Метою дослідження $є$ визначення пружних властивостей гнучкого трубопроводу на прикладі НПР типу «Т» із внутрішнім діаметром 150 мм під час розтягу в умовах статичних циклів навантаження-розвантаження у поздовжньому (вздовж основи) напрямку.

Для досягнення мети були поставлені такі завдання:

- провести експериментальні дослідження з визначення жорсткості напірних пожежних рукавів;

- провести експериментальні дослідження з визначення дисипативних властивостей напірних пожежних рукавів.

\section{4. Матеріали та методи дослідження в'язкопружних властивостей рукава}

3 метою визначення дисипативних властивостей матеріалу НПР типу «Т» 3 внутрішнім діаметром 150 мм було проведено низку натурних експериментів 3 розтягу в умовах статичних циклів навантаження-розвантаження 3 подальшою обробкою результатів.

Конструкцію НПР було розглянуто у роботі [10]. Так було визначено модулі пружності та дисипативні властивості НПР типу «Т» із внутрішнім діаметром 66 мм в поздовжньому напрямку (уздовж осі рукава).

Для проведення випробувань було використано дослідну установку ДМ-30М (Завод випробувальних машин, СРСР) в якій зразок рукава фіксувався за допомогою механічного затискача. Задавалися фіксовані значення деформації зразків. За допомогою штатного динамометра вимірювалась навантаження. Експерименти проводились з метою визначення в'язкопружних властивостей рукава, у поздовжньому напрямку. Дослідження проводились 3 дев'ятьма зразками які були відокремлені від різних ділянок нових НПР діаметром 150 мм при цьому зразки навантажувались 3 постійним подовженням зразка ( $\Delta=0,5$ мм).

Дослідні зразки (фрагменти) матеріалу (рис. 1), які було відокремлено від пожежного рукава типу «Т» діаметром d=150 мм, мали наступні розміри:

- випробувальна довжина l=155 мм,

- ширина $b=87$ мм,

- товщина $\delta=2,5$ мм. 


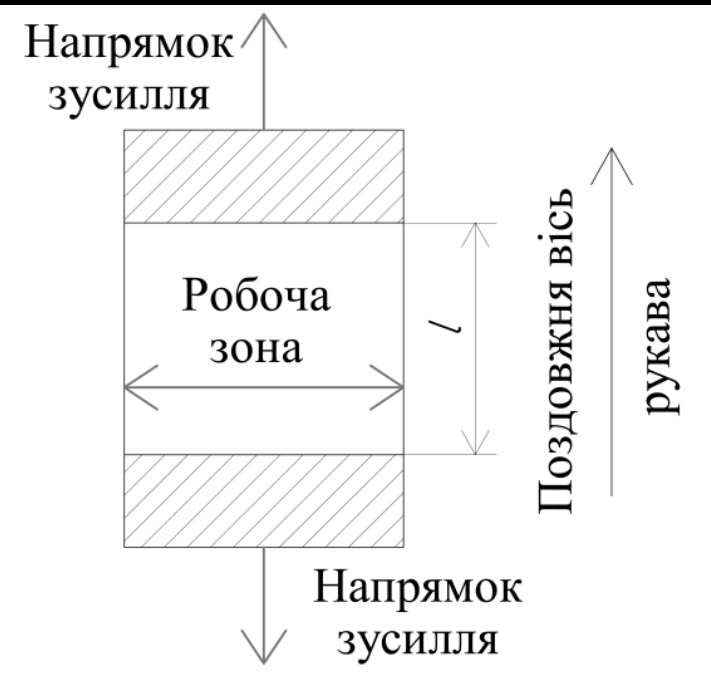

Рис. 1. Випробувальний зразок матеріалу пожежного рукава

Експерименти проводились в двох окремих варіантах. Першими було проведено експерименти на визначення жорсткості у поздовжньому напрямку. Другим варіантом експериментів були випробування на визначення в'язкопружних (дисипативних) властивостей матеріалу.

Для перевірки їх повторюваності, кожен експеримент проводився 9 разів. Зразки були відокремлені від різних ділянок, різних рукавів 3 наступною статистичною обробкою результатів.

\section{5. Дослідження поздовжньої жорсткості напірних пожежних рукавів ді- аметром 150 мм}

Результати експериментальних досліджень матеріалу напірного пожежного рукава типу «Т» 3 внутрішнім діаметром 150 мм наведені в табл. 1.

Табл. 1. Результати експериментальних випробувань матеріалу рукава

\begin{tabular}{|c|c|c|c|c|c|}
\hline \multirow{2}{*}{$\begin{array}{c}\text { Деформація } \\
\Delta \ell, \text { мм }\end{array}$} & \multicolumn{5}{|c|}{ Навантаження $-F, \mathrm{H}$} \\
\hline & Цикл 1 & Цикл 2 & Цикл 3 & Цикл 4 & Цикл 5-7 \\
\hline 0,0 & 0 & - & - & - & - \\
\hline 0,5 & 96 & - & - & - & - \\
\hline 1,0 & 168 & - & - & - & - \\
\hline 1,5 & 240 & - & - & - & - \\
\hline 2,0 & 264 & - & - & - & - \\
\hline 2,5 & 288 & - & - & - & - \\
\hline 3,0 & 336 & - & - & - & - \\
\hline 3,5 & 432 & - & - & - & - \\
\hline 4,0 & 480 & - & - & - & - \\
\hline 4,5 & 528 & - & - & - & - \\
\hline 5,0 & 576 & - & - & - & - \\
\hline 5,5 & 648 & - & - & - & - \\
\hline 6,0 & 720 & 0 & - & - & - \\
\hline 6,5 & 768 & 192 & - & - & - \\
\hline 7,0 & 816 & 288 & - & - & - \\
\hline 7,5 & 888 & 432 & 0 & 0 & 0 \\
\hline 8,0 & 936 & 576 & 168 & 192 & 240 \\
\hline
\end{tabular}




\begin{tabular}{|c|c|c|c|c|c|}
\hline \multicolumn{9}{|c|}{ Продовження табл. 1. } \\
\hline 8,5 & 984 & 720 & 312 & 336 & 432 \\
\hline 9,0 & 1080 & 840 & 456 & 480 & 576 \\
\hline 9,5 & 1176 & 960 & 624 & 648 & 720 \\
\hline 10,0 & 1248 & 1080 & 720 & 768 & 864 \\
\hline 10,5 & 1296 & 1200 & 912 & 960 & 1008 \\
\hline 11,0 & 1416 & 1296 & 1032 & 1104 & 1200 \\
\hline 11,5 & 1464 & 1392 & 1200 & 1224 & 1392 \\
\hline 12,0 & 1512 & 1440 & 1296 & 1416 & 1416 \\
\hline 12,5 & 1536 & 1512 & 1440 & 1440 & 1440 \\
\hline
\end{tabular}

Початковий цикл (1) навантаження-розвантаження проводився з недеформованим фрагментом пожежного рукава довжиною 155 мм.

Максимальна величина деформації становила $\Delta \mathrm{l}_{1}^{\max }=12,5 \cdot 10^{-3} \mathrm{M}$, при навантаженні $\mathrm{F}_{1}^{\max }=1536 \mathrm{H}$. Після розвантаження залишкова деформація фрагменту становила $\Delta \mathrm{l}_{1}^{\text {зал }}=6,0 \cdot 10^{-3} \mathrm{M}$.

При повторному циклі (2), який було проведено через дві хвилини після першого, максимальна величина деформації становила $\Delta \mathrm{l}_{2}^{\max }=12,5 \cdot 10^{-3}$ м, при навантаженні $\mathrm{F}_{2}^{\max }=1512$ Н. Після розвантаження залишкова деформація фрагменту становила $\Delta \mathrm{l}_{2}^{\text {зал }}=7,5 \cdot 10^{-3} \mathrm{M}$.

При третьому циклі (3), максимальна величина деформації становила $\Delta \mathrm{l}_{3}^{\max }=12,5 \cdot 10^{-3} \mathrm{M}$, при навантаженні $\mathrm{F}_{3}^{\max }=1440$ Н. Після розвантаження залишкова деформація фрагменту становила $\Delta \mathrm{l}_{3}^{\text {зал }}=7,5 \cdot 10^{-3} \mathrm{M}$.

При четвертому циклі (4), максимальна величина деформації становила $\Delta \mathrm{l}_{4}^{\max }=12,5 \cdot 10^{-3} \mathrm{M}$, при навантаженні $\mathrm{F}_{4}^{\max }=1440 \mathrm{H}$. Після розвантаження залишкова деформація фрагменту становила $\Delta \mathrm{l}_{4}^{\text {зал }}=7,5 \cdot 10^{-3}$ м.

Числові параметри наступних трьох циклів навантаження-розвантаження (57), які було проведено з аналогічними двохвилинними інтервалами, практично не відрізняються один від одного, що дозволило їх усереднити. Максимальна величина деформації на цих режимах становила $\Delta \mathrm{l}_{5-7}^{\max }=12,5 \cdot 10^{-3} \mathrm{M}$, при середньому навантаженні $\mathrm{F}_{5-7}^{\max }=1440$ Н. Залишкова деформація фрагменту після розвантаження була відсутня, тобто $\Delta \mathrm{l}_{5-7}^{\text {зал }}=0$.

Навантаження та деформація фрагментів пожежних рукавів дозволяє визначити в першому наближенні (без урахування зміни розмірів зразка внаслідок деформаціï) усереднену жорсткість $(C)$ його матеріалу в поздовжньому напрямку:

$$
\mathrm{C}_{\mathrm{i}}=\frac{\mathrm{F}_{\mathrm{i}}^{\max }}{\Delta \mathrm{l}_{\mathrm{i}}^{\max }},
$$

де $\mathrm{C}_{\mathrm{i}}$ - усереднена жорсткість, визначена для i-го циклу; $\mathrm{F}_{\mathrm{i}}^{\max }$ - максимальне навантаження i-го циклу; $\Delta \mathrm{l}_{\mathrm{i}}^{\max }-$ максимальна деформація і-го циклу.

3 урахуванням статистично оброблених експериментальних даних (табл. 1) для відповідних циклів навантаження усереднена жорсткість становить: 


$$
\begin{gathered}
\mathrm{C}_{1}=122,88 \kappa \mathrm{H} / \mathrm{M} ; \\
\mathrm{C}_{2}=232,615 \kappa \mathrm{H} / \mathrm{m} ; \\
\mathrm{C}_{3}=292,8 \kappa \mathrm{\kappa} / \mathrm{M} ; \\
\mathrm{C}_{4}=288 \kappa \mathrm{\kappa} / \mathrm{M} ; \\
\mathrm{C}_{5-7}=283,2 \kappa \mathrm{H} / \mathrm{M} .
\end{gathered}
$$

Таким чином, визначено жорсткості які при перших двох-трьох режимах навантаження спочатку збільшуються, а потім на 4-7 випробуваннях стабілізуються на рівні 283 кН/м.

\section{6. Дослідження дисипативних властивостей напірних пожежних рукавів

\begin{tabular}{|c|c|c|c|c|c|c|c|c|c|c|}
\hline \multirow{3}{*}{$\begin{array}{c}\text { Деформація } \Delta \ell, \\
\text { мм }\end{array}$} & \multicolumn{10}{|c|}{ Навантаження - F, H } \\
\hline & \multicolumn{2}{|c|}{ Цикл 1} & \multicolumn{2}{|c|}{ Цикл 2} & \multicolumn{2}{|c|}{ Цикл 3} & \multicolumn{2}{|c|}{ Цикл 4} & \multicolumn{2}{|c|}{ Цикл 5-7 } \\
\hline & $\mathrm{H}$ & $\mathrm{P}$ & $\mathrm{H}$ & $\mathrm{P}$ & $\mathrm{H}$ & $\mathrm{P}$ & $\mathrm{H}$ & $\mathrm{P}$ & $\mathrm{H}$ & $\mathrm{P}$ \\
\hline 0,0 & 0 & - & - & - & - & - & - & - & - & - \\
\hline 0,5 & 96 & - & - & - & - & - & - & - & - & - \\
\hline 1,0 & 168 & - & - & - & - & - & - & - & - & - \\
\hline 1,5 & 240 & - & - & - & - & - & - & - & - & - \\
\hline 2,0 & 264 & - & - & - & - & - & - & - & - & - \\
\hline 2,5 & 288 & - & - & - & - & - & - & - & - & - \\
\hline 3,0 & 336 & - & - & - & - & - & - & - & - & - \\
\hline 3,5 & 432 & - & - & - & - & - & - & - & - & - \\
\hline 4,0 & 480 & - & - & - & - & - & - & - & - & - \\
\hline 4,5 & 528 & - & - & - & - & - & - & - & - & - \\
\hline 5,0 & 576 & - & - & - & - & - & - & - & - & - \\
\hline 5,5 & 648 & - & - & - & - & - & - & - & - & - \\
\hline 6,0 & 720 & 0 & 0 & - & - & - & - & - & - & - \\
\hline 6,5 & 768 & 48 & 192 & - & - & - & - & - & - & - \\
\hline 7,0 & 816 & 120 & 288 & - & - & - & - & - & - & - \\
\hline 7,5 & 888 & 240 & 432 & 0 & 0 & 0 & 0 & 0 & 0 & 0 \\
\hline 8,0 & 936 & 336 & 576 & 48 & 240 & 24 & 192 & 24 & 168 & 24 \\
\hline 8,5 & 984 & 480 & 720 & 120 & 432 & 48 & 336 & 48 & 312 & 72 \\
\hline 9,0 & 1080 & 648 & 840 & 192 & 576 & 72 & 480 & 96 & 456 & 144 \\
\hline 9,5 & 1176 & 840 & 960 & 288 & 720 & 144 & 648 & 192 & 624 & 216 \\
\hline 10,0 & 1248 & 960 & 1080 & 384 & 864 & 264 & 768 & 288 & 720 & 312 \\
\hline 10,5 & 1296 & 1104 & 1200 & 480 & 1008 & 408 & 960 & 432 & 912 & 432 \\
\hline 11,0 & 1416 & 1176 & 1296 & 672 & 1200 & 480 & 1104 & 552 & 1032 & 600 \\
\hline 11,5 & 1464 & 1248 & 1392 & 864 & 1392 & 672 & 1224 & 720 & 1200 & 768 \\
\hline 12,0 & 1512 & 1368 & 1440 & 1128 & 1416 & 936 & 1416 & 984 & 1296 & 1008 \\
\hline 12,5 & 1536 & 1536 & 1512 & 1512 & 1464 & 1464 & 1440 & 1440 & 1416 & 1416 \\
\hline
\end{tabular} діаметром 150 мм}

Результати експериментальних досліджень матеріалу напірного пожежного рукава типу «Т» 3 внутрішнім діаметром 150 мм наведені в табл. 2.

Табл. 2. Результати експериментальних випробувань матеріалу рукава

Результати експериментальних досліджень матеріалу напірних пожежних рукавів діаметром 150 мм (табл. 2) засобом Microsoft Excel 2007 апроксимовані відповідними трендами, графіки яких наведені на рис. 2-6.

158 ○ С. Ю. Назаренко, Г. О. чернобай, о. М. колєнов, П. Ю. Бородич та ін. 


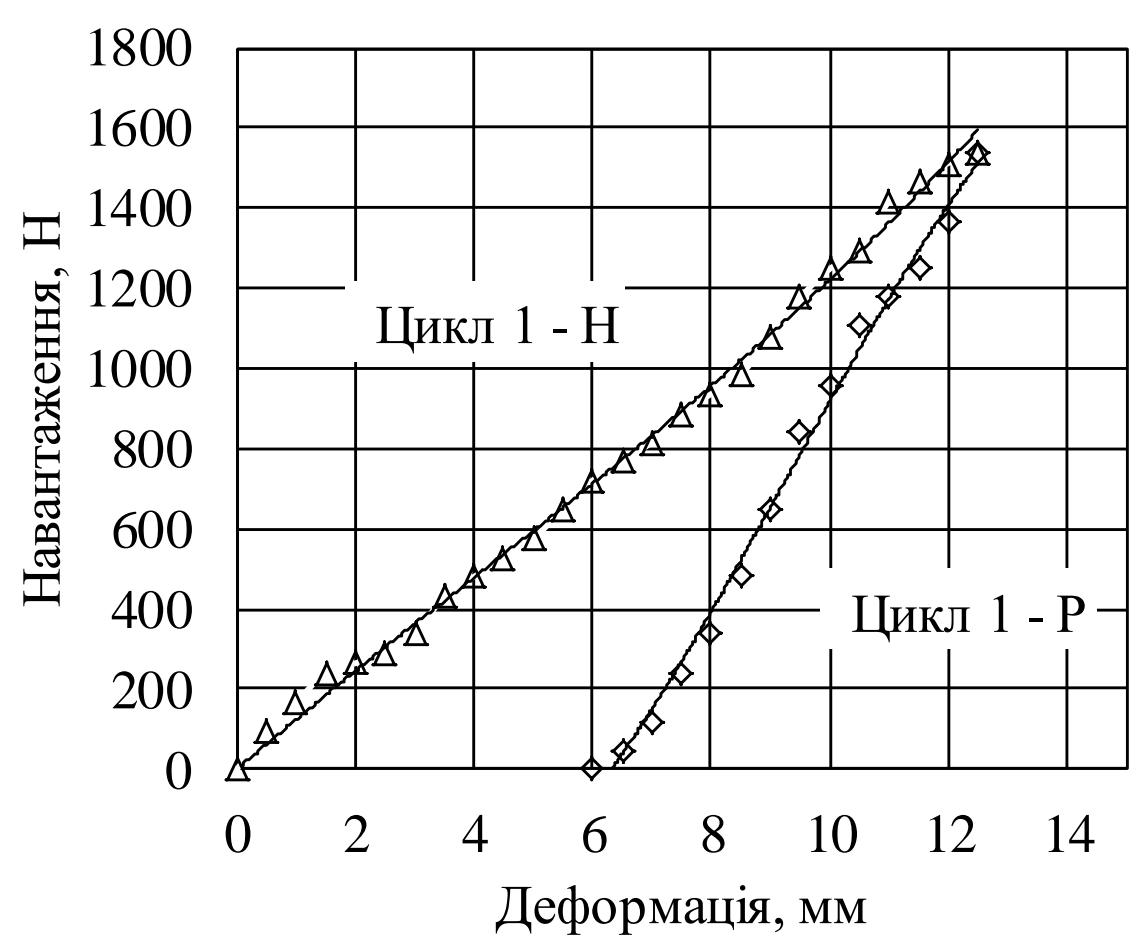

Рис. 2. Крива деформування зразку НПР. Цикл 1. Н - навантаження Р розвантаження

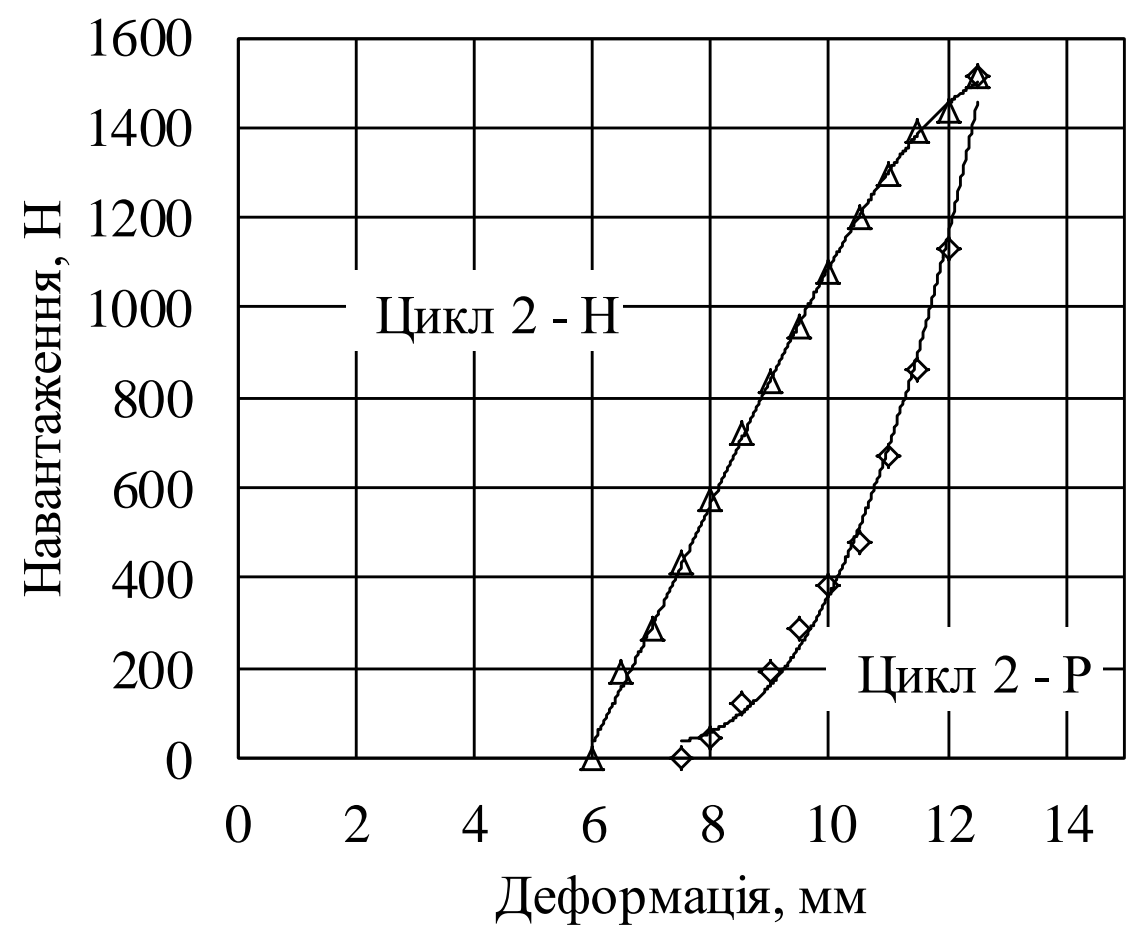

Рис. 3. Крива деформування зразку НПР. Цикл 2. Н - навантаження Р розвантаження

На рис. 3 відповідають поліноміальним трендам циклу 2 навантаженнярозвантаження фрагментів матеріалу НПР. 


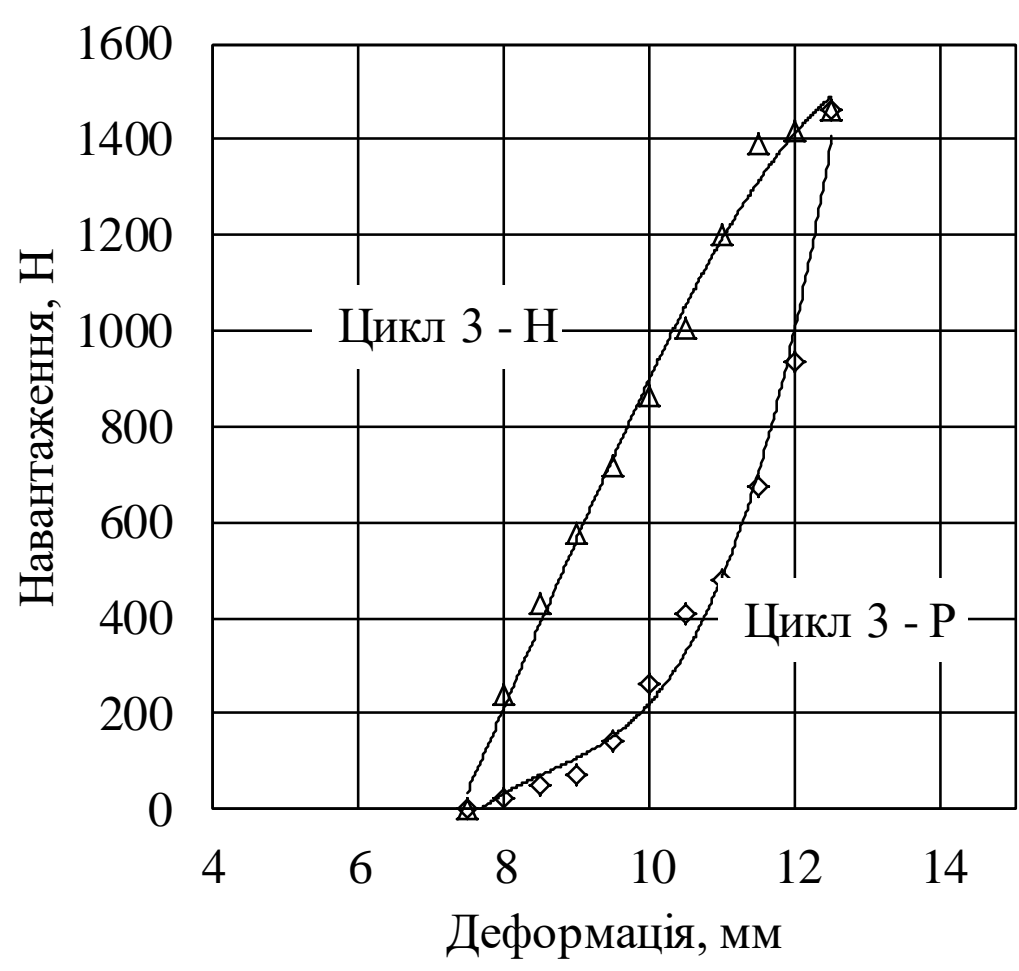

Рис. 4. Крива деформування зразку гідроізолюючого шару. Цикл 3. Н - навантаження $\mathrm{P}$ - розвантаження

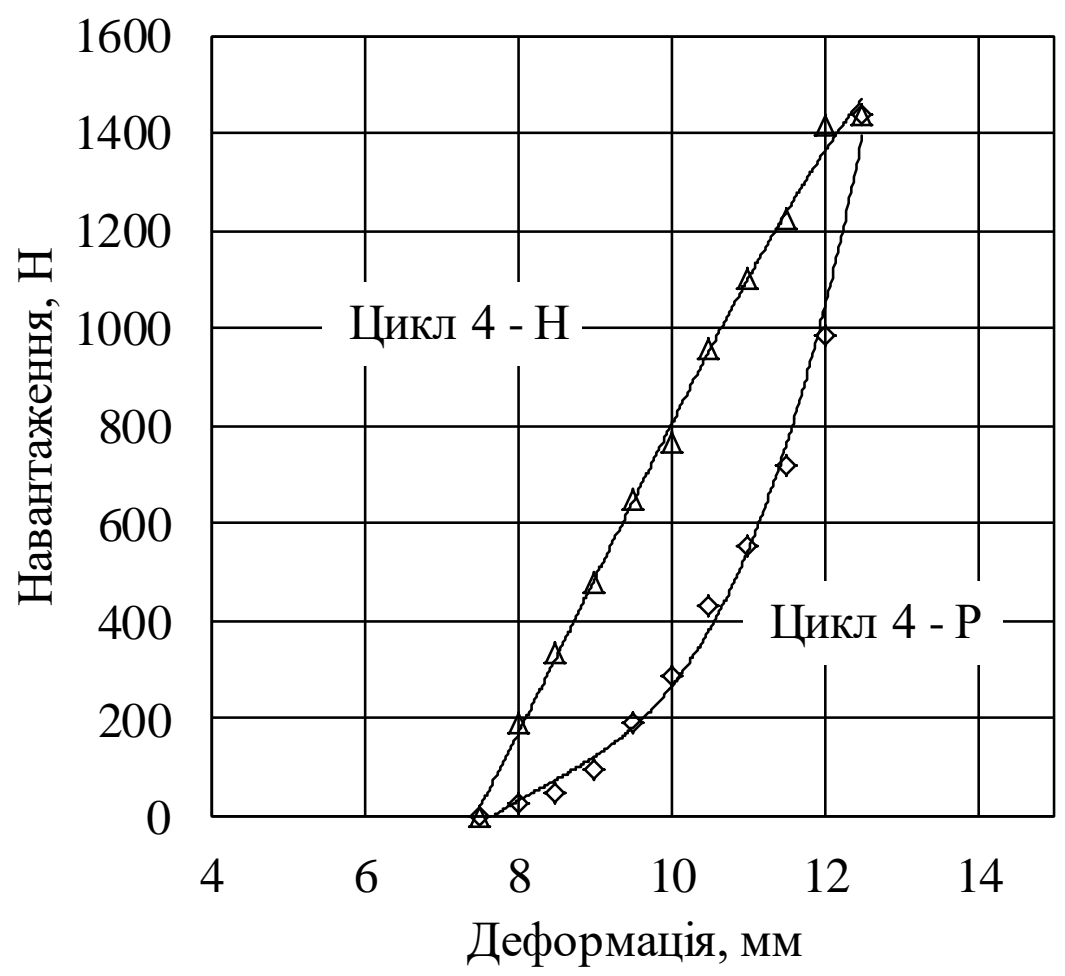

Рис. 5. Крива деформування зразку НПР. Цикл 4. Н - навантаження Р розвантаження

На рис. 5 відповідають поліноміальним трендам циклу 4 навантаженнярозвантаження фрагментів матеріалу НПР. 


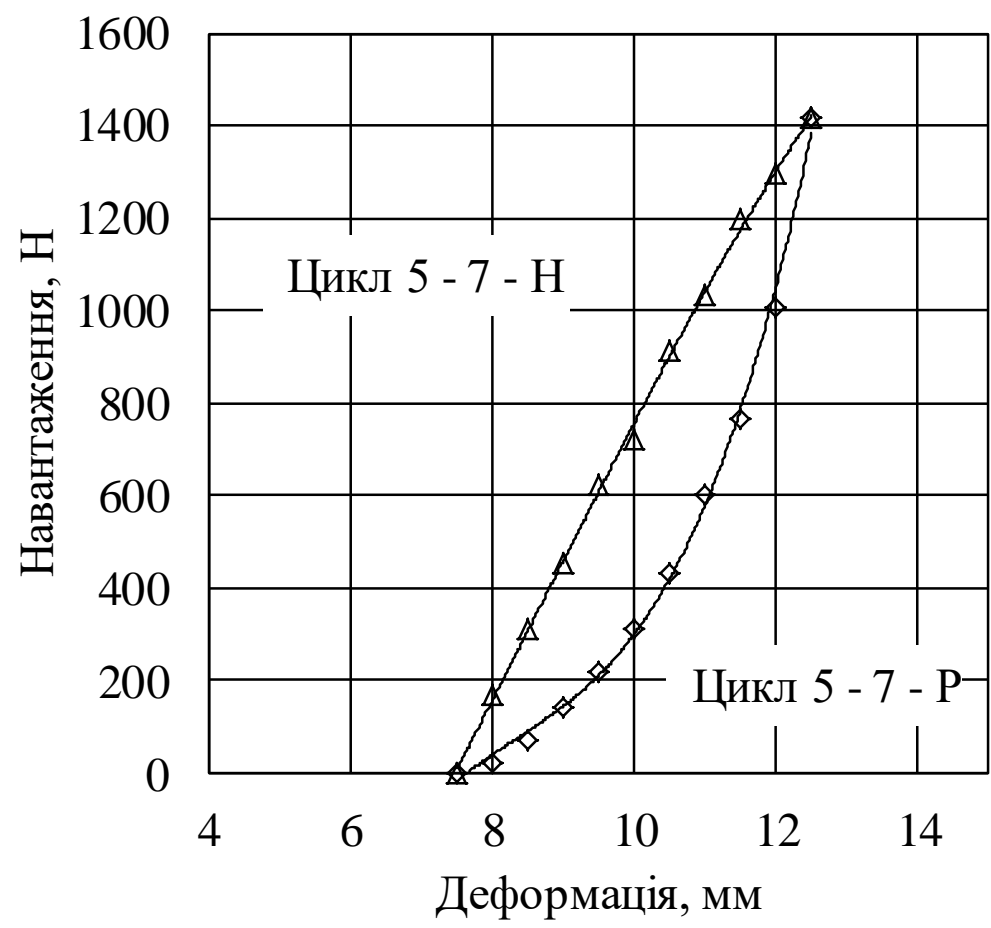

Рис. 6. Крива деформування зразку НПР. Цикл 5-7. Н - навантаження Р розвантаження

Отримані залежності шляхом використання табличного процесора Microsoft Excel 2007 були апроксимовані лінією тренду. Види ліній тренду обиралися на основі розрахованого значення коефіцієнту детермінації, який характеризує ступінь близькості вказаних ліній до вихідних даних.

Одержані лінії тренду описують відповідні рівняння які наведені в табл. 3.

Табл. 3. Рівняння регресії та ступінь достовірності процесів матеріалу армуючого каркасу

\begin{tabular}{|c|c|c|}
\hline Цикл № & $\begin{array}{c}\text { Рівняння залежності діючого навантажень ( }) \text { від деформації } \\
(\mathrm{x})\end{array}$ & $\begin{array}{c}\text { Ступінь достові- } \\
\text { рності }\end{array}$ \\
\hline $1-\mathrm{H}$ & $\mathrm{y}=0.2109 \mathrm{x}^{3}-2.5449 \mathrm{x}^{2}+126.38 \mathrm{x}$ & $\mathrm{R}^{2}=0.9967$ \\
\hline $1-\mathrm{P}$ & $\mathrm{y}=-2.1412 \mathrm{x}^{3}+59.856 \mathrm{x}^{2}-292.65 \mathrm{x}$ & $\mathrm{R}^{2}=0.9935$ \\
\hline $2-\mathrm{H}$ & $\mathrm{y}=-3.2958 \mathrm{x}^{3}+78.479 \mathrm{x}^{2}-346.12 \mathrm{x}$ & $\mathrm{R}^{2}=0.999$ \\
\hline $2-\mathrm{P}$ & $\mathrm{y}=3.9196 \mathrm{x}^{3}-56.053 \mathrm{x}^{2}+204.9 \mathrm{x}$ & $\mathrm{R}^{2}=0.995$ \\
\hline $3-\mathrm{H}$ & $\mathrm{y}=-4.5066 \mathrm{x}^{3}+113.01 \mathrm{x}^{2}-589.2 \mathrm{x}$ & $\mathrm{R}^{2}=0.9941$ \\
\hline $3-\mathrm{P}$ & $\mathrm{y}=18.089 \mathrm{x}^{3}-467.69 \mathrm{x}^{2}+4099.9 \mathrm{x}-12095$ & $\mathrm{R}^{2}=0.99$ \\
\hline $4-\mathrm{H}$ & $\mathrm{y}=-3.2359 \mathrm{x}^{3}+87.813 \mathrm{x}^{2}-474.33 \mathrm{x}$ & $\mathrm{R}^{2}=0.9974$ \\
\hline $4-\mathrm{P}$ & $\mathrm{y}=13.688 \mathrm{x}^{3}-343.05 \mathrm{x}^{2}+2952.1 \mathrm{x}-8638.5$ & $\mathrm{R}^{2}=0.9945$ \\
\hline $5-7-\mathrm{H}$ & $\mathrm{y}=-1.7156 \mathrm{x}^{3}+44.755 \mathrm{x}^{2}-87.403 \mathrm{x}-1129.5$ & $\mathrm{R}^{2}=0.9988$ \\
\hline $5-7-\mathrm{P}$ & $\mathrm{y}=12.047 \mathrm{x}^{3}-299.97 \mathrm{x}^{2}+2590.6 \mathrm{x}-7655.3$ & $\mathrm{R}^{2}=0.9976$ \\
\hline
\end{tabular}

За допомогою рівняння (1) визначаємо енергію $\left(\mathrm{A}_{д}\right)$, що накопичується в зразку.

$$
\mathrm{A}_{\text {д }}=\mathrm{A}_{\mathrm{H}}-\mathrm{A}_{\mathrm{P}}=\int_{\Delta \ell_{\mathrm{H}}}^{\Delta \ell_{\mathrm{HK}}} \mathrm{F}_{\mathrm{H}}(\Delta \ell) \mathrm{d}(\Delta \ell)-\int_{\Delta \ell_{\mathrm{PK}}}^{\Delta \ell_{\mathrm{PI}}} \mathrm{F}_{\mathrm{P}}(\Delta \ell) \mathrm{d}(\Delta \ell),
$$

де $\mathrm{F}_{\mathrm{H}}(\Delta \ell)$ - рівняння залежності діючої сили від деформації зразка при його навантаженні; $\mathrm{F}_{\mathrm{P}}(\Delta \ell)$ - рівняння залежності діючої сили від деформації зразка при йоCivi1 Security. DOI: 10.52363/2524-0226-2021-33-12 
го розвантаженні; $\Delta \ell_{\text {нп }}\left(\Delta \ell_{\text {нК }}\right)$ - нижня (верхня) межа інтегрування, що відповідає початковій точці навантаження; $\Delta \ell_{\text {РК }}\left(\Delta \ell_{\text {РП }}\right)-$ нижня (верхня) межа інтегрування, що відповідає кінцевій точці розвантаження.

Енергія $\left(\mathrm{A}_{д}\right)$ відповідає дисипативним властивостям матеріалу рукава, що визначається площею петлі гістерезису як різниця робіт, витрачених при навантаженні $\left(\mathrm{A}_{\mathrm{H}}\right)$ і наступному розвантаженні $\left(\mathrm{A}_{\mathrm{P}}\right)$ зразка. За допомогою рівняння (2) визначаємо коефіцієнтом дисипації ( $\beta$ ).

$$
\beta=\frac{A_{\text {Д }}}{A_{H}}
$$

Результати відповідних розрахунків наведені в табл. 4.

Табл. 4. Результати розрахунків експериментальних випробувань матеріалу зовнішнього тканинного армуючого каркасу

\begin{tabular}{|c|c|c|c|c|c|}
\hline $\begin{array}{c}\text { Характеристика, позначення, } \\
\text { розмірність }\end{array}$ & Цикл 1 & Цикл 2 & Цикл 3 & Цикл 4 & Цикли 5-7 \\
\hline $\begin{array}{c}\text { Енергія при навантаженні, } \\
\qquad \mathrm{A}_{\mathrm{H}}, \text { Дж·10 } 0^{-3}\end{array}$ & 9503.83 & 5584.02 & 4280.88 & 3914 & 3711.92 \\
\hline $\begin{array}{c}\text { Енергія при розвантаженні, } \\
\mathrm{A}_{\mathrm{P}}, \text { Дж· } 10^{-3}\end{array}$ & 4688.43 & 2457.49 & 1901.04 & 2031.56 & 2143.5 \\
\hline $\begin{array}{c}\text { Енергія дисипації, } \\
\mathrm{A}_{\text {д }}, \text { Дж } 10^{-3}\end{array}$ & 4815.4 & 3126.53 & 2379.84 & 1882.44 & 1568.42 \\
\hline Коефіцієнт дисипації, $\beta$ & 0.51 & 0.56 & 0.56 & 0,48 & 0.42 \\
\hline
\end{tabular}

Загальні результати проведеного експерименту з випробувань на розтяг матеріалу рукава із внутрішнім діаметром 150 мм в поздовжньому напрямку в табл. 5 .

Табл. 5. Зведена таблиця результатів експериментальних досліджень деяких механічних властивостей пожежного рукава

\begin{tabular}{|c|c|c|c|c|c|c|}
\hline Характеристика & Позначення & $\begin{array}{c}\text { Цикл } \\
\text { № 1 }\end{array}$ & $\begin{array}{c}\text { Цикл } \\
\text { № 2 }\end{array}$ & $\begin{array}{c}\text { Цикл } \\
\text { №3 }\end{array}$ & $\begin{array}{c}\text { Цикл } \\
\text { № 4 }\end{array}$ & $\begin{array}{c}\text { Цикл } \\
\text { № 5-7 }\end{array}$ \\
\hline $\begin{array}{c}\text { Максимальне } \\
\text { навантаження }\end{array}$ & $\mathrm{F}_{\max }, \mathrm{H}$ & 1536 & 1512 & 1464 & 1440 & 1416 \\
\hline $\begin{array}{c}\text { Максимальна } \\
\text { деформація }\end{array}$ & $\Delta \ell^{\mathrm{max}}$, мм & 12,5 & 12,5 & 12,5 & 12,5 & 12,5 \\
\hline $\begin{array}{c}\text { Залишкова } \\
\text { деформація }\end{array}$ & $\Delta \ell^{\text {зал }, \text { мм }}$ & 6,0 & 1,5 & 0 & 0 & 0 \\
\hline $\begin{array}{c}\text { Приведена } \\
\text { жорсткість }\end{array}$ & $\mathrm{C}$, кН/м & 122.9 & 232.6 & 292,8 & 288 & 283.2 \\
\hline $\begin{array}{c}\text { Коефіціснт } \\
\text { дисипації }\end{array}$ & $\beta$ & 0.51 & 0.56 & 0.56 & 0,48 & 0.42 \\
\hline
\end{tabular}

В табл. 5 наведено максимальне навантаження, максимальна деформація, залишкова деформація, приведена жорсткість, модуль пружності та коефіцієнт дисипації для матеріалу рукава. 


\section{7. Обговорення результатів дослідження пружних та дисипативних вла- стивостей напірних пожежних рукавів}

За результатами проведення експериментальних досліджень було визначено в'язкопружні та дисипативні властивості напірного пожежного рукава типу «Т» діаметром 150 мм. Визначено, що значний початковий гістерезис фрагменту пожежного рукава (рис. 2-5) при повторних випробуваннях (цикли 5-7) значно зменшуються (рис. 6). Це разом із зменшенням залишкових деформацій та стабілізацією пружних властивостей (табл. 5) наближає поведінку матеріалу рукава в поздовжньому напрямку до пружного.

Встановлено зміну властивостей матеріалу пожежного рукава при послідовних циклах деформацій навантаження-розвантаження є зворотною, проміжки між циклами деформування призводять до часткового відновлення механічних характеристик, наближаючи їх до початкових значень. Час релаксації, що в значній мірі залежить від величини попередньої відносної деформації, становить від кількох годин до кількох діб.

Порівнявши раніше отримані результати [10] з отриманими, можна сказати, що, по-перше, конструктивно рукави однакові. По-друге, при збільшенні діаметру рукава, збільшується товщина матеріалу НПР, а саме, збільшується як товщина армуючого каркасу так і внутрішнього гідроізолюючого гумового шару. По-третє, для визначення сталих показників, необхідно повторюваність проведення експерименту.

Експериментальні дослідження були обмежені одним типом рукава та не враховувалась його зношеності.

Ці обмеження можуть бути усунені шляхом дослідження напірного рукава 3 довільним терміном використання, та проведення випробувань на різних типах пожежних рукавів.

Подальшим розвитком відповідних досліджень $є$ експериментальний аналіз впливу штучного дефекту, вплив високих температур на механічні властивості матеріалу рукава. при цьому слід розглянути різні типи рукавів 3 довільним терміном їх використання.

\section{8. Висновки}

1. Проведено експериментальні дослідження з визначення приведеної жорсткості напірного пожежного рукава типу «Т» діаметром 150 мм при статичних циклах навантаження-розвантаження в поздовжньому напрямку. Так зміна властивостей матеріалу рукава при послідовних циклах деформацій навантаженнярозвантаження є зворотною, проміжки між циклами деформування призводять до часткового відновлення механічних характеристик, наближаючи їх до початкових значень. Встановлено, що приведена жорсткість матеріалу рукава в поздовжньому напрямку стабілізувався на рівні 283,2 кН/м. При цьому величина приведеної жорсткості при майже однаковому діапазоні навантаження $(1416 \div 1536 \mathrm{H})$, збільшувалися від 122,9 до 292,8 кН/м (цикл 1-3) і лише потім (цикл 4) жорсткість, зменшується, а на наступних - стабілізувалися (цикл 5-7), при суттєвому змен-

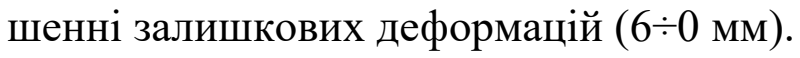

2. Проведено експериментальні дослідження 3 визначення дисипативних властивостей напірного пожежного рукава типу «Т» діаметром 150 мм при статичних циклах навантаження-розвантаження в поздовжньому напрямку. Для узагальнення експериментальних досліджень результати апроксимовано відповідни- 
ми лініями трендів. Було визначено криві деформування зразків, що в умовах циклічного навантаження-розвантаження формували петлі гістерезису. Отримані петлі гістерезису в ході дослідження показали, що при перших двох режимах петлі зазнають кількісних та якісних змін, а саме, зменшується нахил петлі гістерезису та ії площа. Встановлено, що коефіцієнт дисипації матеріалу рукава стабілізувався на рівні 0,42. При цьому його величина при майже однаковому діапазоні навантаження $(1416 \div 1536 \mathrm{H})$, спочатку збільшується від 0,51 до 0,56, на наступних циклах деформації (цикл 4) коефіцієнт дисипації зменшується до 0,48 та стабілізуються на 5-7 циклах на рівні 0,42.

\section{Література}

1. Lee G. -C., Kim H. -E., Park J. -W., Jin H. -L., Lee Y. -S., Kim J., -H. An expermental study and finite element analysis for finding leakage path in high pressure hose assembly. International Journal of Precision Engineering and Manufacturing. 2011. V. 12 (3). P. 537-542. doi: 10.1007/s12541-011-0067-y

2. Pavlouskova Z., Klakurkova L., Man O. Celko L., Svejcar J. Assessment of the cause of cracking of hydraulic hose clamps. Engineering Failure Analysis. 2015. V. 56. P. 14-19. doi: 10.1016/j.engfailanal.2015.05.014

3. Dong-Hyun Y., Beom-Seon J., Ki-Ho Y. Nonlinear finite element analysis of failure modes and ultimate strength of flexible pipes. Marine Structures. 2017. №54. P. 50-72. doi: 10.1016/j.marstruc.2017.03.007

4. Haseeb A., Jun T., Fazal M., Masjuki H. Degradation of physical properties of different elastomers upon exposure to palm biodiesel. Energy. 2011. №36 (3). P. 18141819. doi: 10.1016/j.energy.2010.12.023

5. Cho J., Yoon Y., Seo C., Kim Y. Fatigue life assessment of fabric braided composite rubber hose in complicated large deformation cyclic motion. Finite Elements in Analysis and Design. 2015. №100. P. 65-76. doi: 10.1016/j.finel. 2015.03.002

6. Cho J., Yoon Y. Large deformation analysis of anisotropic rubber hose along cyclic path by homogenization and path interpolation methods. Journal of Mechanical Science and Technology. 2016. №30. P. 789-795. doi: 10.1007/ s12206-016-0134-5

7. Roland T., David M., Oliver S., Roman L. Mechanical performance of textilereinforced hoses assessed by a truss-based unit cell model. International Journal of Engineering Science. 2019. V. 141. P. 47-66. doi: 10.1016/j. ijengsci. 2019.05.006

8. Larin O. Probabilistic model of fatigue damage accumulation in rubberlike materials. Strength of Materials. 2015. V. 47. Is. 6. P. 849-858.

9. Larin O., Morozov O., Nazarenko S., Chernobay G., Kalynovskyi A., Kovalenko R., Fedulova S., Pustovoitov P. Determining mechanical properties of a pressure fire hose the type of «T». Eastern-European Journal Of Enterprise Technologies. 2019. V. 6 (7 (102)). P. 63-70. doi: 10.15587/1729-4061.2019.184645

10. Nazarenko S., Kovalenko R., Asotskyi V., Chernobay G., Kalynovskyi A., Tsebriuk I., Shapovalov O., Shasha I., Demianyshyn V., Demchenko A. Determining mechanical properties at the shear of the material of «T» type pressure fire hose based on torsion tests. Eastern-European Journal Of Enterprise Technologies. 2020. V. 5 (7 (107)). P. 45-55. doi: 10.15587/1729-4061.2020.212269

11. Fedorko G., Molnar V., Dovica M., Toth T., Fabianova J. Failure analysis of irreversible changes in the construction of the damaged rubber hoses. Engineering Failure Analysis. 2015. V. 58. P. 31-43.

164 ○ С. Ю. назаренко, Г. О. чернобай, о. М. колєнов, П. Ю. Бородич та ін. 
12. Степанов О., Братолюбова Е., Широков, А. Исследование влияния различных факторов на прочность напорных пожарных рукавов при гидравлическом воздействии. Технология текстильной промышленности. 2012. № 4. С. 105-108.

\author{
S. Nazarenko, PhD, Associate Professor, Associate Professor of the Department \\ G. Chernobay, PhD, Associate Professor \\ O. Kolienov, PhD, Deputy Head of the Faculty \\ P. Borodych, PhD, Associate Professor, Associate Professor of the Department \\ B. Kryvoshei, PhD, Associate Professor, Associate Professor of the Department \\ $V$. Titarev, Specialist of the Department \\ National University of Civil Defence of Ukraine, Kharkiv, Ukraine
}

\title{
DETERMINATION OF VISCOUSELASTIC PROPERTIES OF PRESSURE FIRE HOSES WITH A DIAMETER OF $150 \mathrm{MM}$
}

The presented experimental studies to determine the viscoelastic characteristics of a pressure head fire hose of the "T" type with an inner diameter of $150 \mathrm{~mm}$ under static load conditions. In the course of the work, a number of full-scale tensile experiments were carried out with a sample under conditions of static loading-unloading cycles. The tests consisted of 7 cycles (mode) of loading-unloading, which were carried out with a two-minute interval. Taking into account the experimental data, the tensile stiffness of the sleeve material in the longitudinal (along the base) direction was determined. It has been established that numerous results of mechanical properties depend on the "history" of the sleeve load, that is, in the first two load modes, the rigidity is given, increased, and only then, in the next ones, they stabilized. This, together with a significant reduction in residual deformations, enhances the elastic properties of the fire hose material. The results of the studies have shown that during the first two cycles the material demonstrates the manifestation of short-term creep, which is stabilized at 5-7 modes. To generalize the experimental studies, the results are approximated by the corresponding trend lines. Deformation curves of the samples were determined under cyclic loading-unloading conditions, which formed hysteresis loops. When analyzing the corresponding curves, it was found that: firstly, during the first two three cycles of loading-unloading, the area of the hysteresis loops decreases. Secondly, the angle of inclination of the hysteresis loops also decreased with each loading-unloading cycle. It was found that the dissipation coefficients of the sleeve material when stretched in the longitudinal direction in the first two or three test modes increases. In subsequent tests (cycle 4-7), the dissipation coefficients decrease and then stabilize at a level of 0.42 .

Keywords: pressure fire hose, elasticity module, rigidity, hysteresis, dissipative properties

\section{References}

1. Lee, G. -C., Kim, H. -E., Park, J. -W., Jin, H. -L., Lee, Y. -S., Kim, J., -H. (2011). An expermental study and finite element analysis for finding leakage path in high pressure hose assembly. International Journal of Precision Engineering and Manufacturing, 12, 3, 537-542. doi: 10.1007/s12541-011-0067-y

2. Pavlouskova, Z., Klakurkova, L., Man, O. Celko, L., Svejcar, J. (2015). Assessment of the cause of cracking of hydraulic hose clamps. Engineering Failure Analysis, 56, 14-19. doi: 10.1016/j.engfailanal.2015.05.014

3. Dong-Hyun, Y., Beom-Seon, J., Ki-Ho, Y. (2017). Nonlinear finite element analysis of failure modes and ultimate strength of flexible pipes. Marine Structures, 54, 50-72. doi: 10.1016/j.marstruc.2017.03.007

4. Haseeb, A., Jun, T., Fazal, M., Masjuki, H. (2011). Degradation of physical properties of different elastomers upon exposure to palm biodiesel. Energy, 36, 3, 1814-1819. doi: 10.1016/j.energy.2010.12.023

5. Cho, J., Yoon, Y., Seo, C., Kim, Y. (2015). Fatigue life assessment of fabric braided composite rubber hose in complicated large deformation cyclic motion. Finite Elements in Analysis and Design, 100, 65-76. doi: 10.1016/j.finel. 2015.03.002 
6. Cho, J., Yoon, Y. (2016). Large deformation analysis of anisotropic rubber hose along cyclic path by homogenization and path interpolation methods. Journal of Mechanical Science and Technology, 30, 2, 789-795. doi: 10.1007/ s12206-016-0134-5

7. Roland, T., David, M., Oliver, S., Roman, L. (2019). Mechanical performance of textile-reinforced hoses assessed by a truss-based unit cell model. International Journal of Engineering Science, 141, 47-66. doi: 10.1016/j.ijengsci. 2019.05.006

8. Larin, O. (2015). Probabilistic model of fatigue damage accumulation in rubberlike materials. Strength of Materials, 47, 6, 849-858.

9. Larin, O., Morozov, O., Nazarenko, S., Chernobay, G., Kalynovskyi, A., Kovalenko, R., Fedulova, S., \& Pustovoitov, P. (2019). Determining mechanical properties of a pressure fire hose the type of «T». Eastern-European Journal Of Enterprise Technologies, 6 (7 (102)), 63-70. doi: 10.15587/1729-4061.2019.184645

10. Nazarenko, S., Kovalenko, R., Asotskyi, V., Chernobay, G., Kalynovskyi, A., Tsebriuk, I., Shapovalov, O., Shasha, I., Demianyshyn, V., Demchenko, A. (2020). Determining mechanical properties at the shear of the material of «T» type pressure fire hose based on torsion tests. Eastern-European Journal Of Enterprise Technologies, 5 (7 (107)), 45-55. doi: 10.15587/1729-4061.2020.212269

11. Fedorko, G., Molnar, V., Dovica, M., Toth, T., Fabianova, J. (2015). Failure analysis of irreversible changes in the construction of the damaged rubber hoses. Engineering Failure Analysis, 58, 31-43. doi: 10.1016/j.engfailanal. 2015.08.042

12. Stepanov, O., Bratoljubova, E., Shirokov, A. (2012). Issledovanie vlijanija razlichnyh faktorov na prochnost' napornyh pozharnyh rukavov pri gidravlicheskom vozdejstvii. Tehnologija tekstil'noj promyshlennosti, 4, 105-108. 